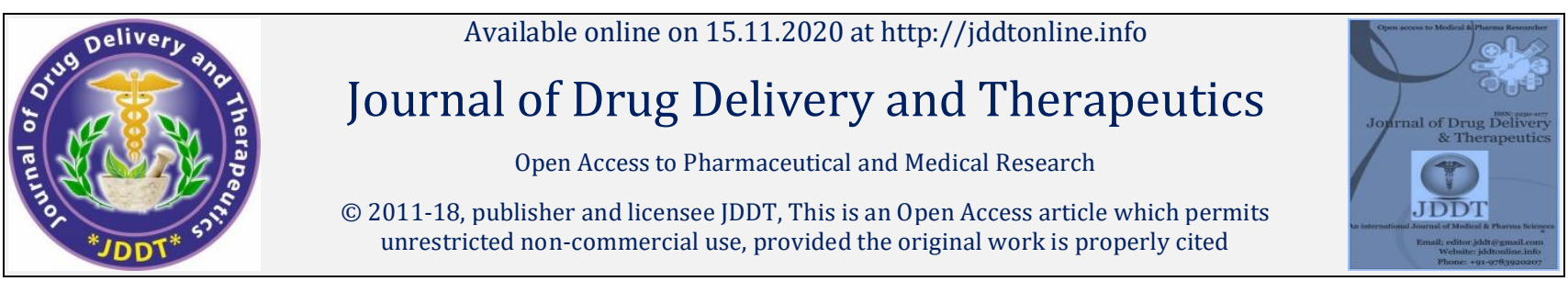

Open $\odot$ Access

Research Article

\title{
Development and Validation of a Green Analytical Method for the Determination of Aspirin and Domperidone Bulk or Formulation Using UV and HPLC
}

\author{
Sneha Jagnade, Pushpendra Soni, Lavakesh Kumar Omray* \\ Radharamn Institute of Pharmaceutical Sciences Bhopal (M.P) 462044 India
}

\begin{abstract}
The aim of present study was to investigate the development and validation of a green analytical method for the determination of aspirin and domperidone. Method Development and Validation for Estimation of Domperidone and Aspirin in bulk or formulation by using RP-HPLC. The $\mathrm{RP}-\mathrm{HPLC}$ method was developed for estimation of Aspirin and Domperidone in synthetic mixture by isocratically using $10 \mathrm{mM}_{\mathrm{KH}} \mathrm{PO}_{4}$ : Acetonitrile (20:80) as mobile phase, Prontosil C-18 column ( $4.6 \times 250 \mathrm{~mm}, 5 \mu$ particle size) column as stationary phase and chromatogram was recorded at $231 \mathrm{~nm}$. Then developed method was validated by using various parameters such as, linearity, Range accuracy, precision repeatability, intermediate precision, robustness, limit of detection, limit of quantification. The proposed methods were found to be linear with correlation coefficient close to one. Precision was determined by repeatability, Intermediate precision and reproducibility of the drugs. The robustness of developed method was checked by changing in the deliberate variation in solvent. The result obtained shows the developed methods to be Cost effective, Rapid (Short retention time), Simple, Accurate (the value of SD and \% RSD less than 2), Precise and can be successfully employed in the routine analysis of these drugs in bulk drug as well as in tablet dosage form. The Simplicity, Rapidly and Reproducibility of the proposed method completely fulfill the objective of this research work.
\end{abstract}

Keywords: Asprin; Domperidone; HPLC; Ultra Violet; Validation

Article Info: Received 24 Aug 2020; $\quad$ Review Completed 18 Oct 2020; $\quad$ Accepted 27 Oct 2020; Available online 15 Nov 2020

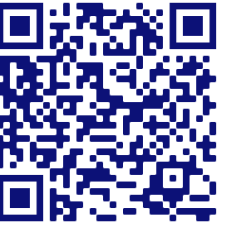

Cite this article as:

Jagnade S, Soni P, Omray LK, Development and Validation of a Green Analytical Method for the Determination of Aspirin and Domperidone Bulk or Formulation Using UV and HPLC, Journal of Drug Delivery and Therapeutics. 2020; 10(6):49-56 http://dx.doi.org/10.22270/jddt.v10i6.4374

Dr. Lavakesh Kumar Omray, Professor, Radharaman Institute of Pharmaceutical Sciences Bhopal (M.P) 462044 India

\section{INTRODUCTION}

Day by day numbers of new drugs are introduced into market. Frequently, there is bigger time period between date of presentation of medication into business sector and date of its incorporation in pharmacopeias. This happens as result of conceivable vulnerabilities in nonstop and more extensive utilization of these medications, report of new toxicities and improvement of patient resistance and presentation of better medications by contenders. In such cases standard scientific strategies for these medications may not be accessible in Pharmacopeias. It gets to be fundamental, in this way, to grow new explanatory system for such medications. Additionally quality is vital in every item or administration in pharmaceuticals as it includes life. Investigation which helps in discovering spatial plan of ion as in particle and vicinity or position of certain natural useful gathering in given compound. What's more surface examination assumes imperative part in material studies to get surface related physical properties, for example, geography, profundity profiling, introduction of atom and so forth. Concoction examination has some fundamental strides like, decision of system, testing, preparatory specimen treatment, partitions, last estimation and appraisal of results. It is with first step viz. decision of system, consideration ought to be practiced to choose best possible instrument to do productive examination. Wrong choice as of right now will prompt good for nothing examination. Analytical methods are broadly classified as Physical, Chemical and Instrumental analysis. Physical observation includes description of compound, measurements of its dimension (shape, size), color, odor etc. Chemical analysis includes titrimetric analysis of compound such as potentiometric, audiometry, argentometry, permagnometry etc. Instrumental methods of chemical analysis have become backbone of experimental chemistry. Method development is done for new products and for existing products. More 
difficulty is short of imminent in equilibrium among wanted and previous understanding to carry out sufficient optimization lesson and enhancement in acquaintance gained through such lesson 1.

An official analytical method is used to assess characterized normal for medication substance or medication item. Option logical technique is proposed by candidate for utilization rather than administrative systematic method. Security testing structures imperative piece of procedure of medication item advancement. reason for soundness testing is to give prove on how nature of medication substance or medication item differs with time affected by mixed bag of ecological components, for example, temperature, moistness, light and empowers suggestion of capacity conditions, retest periods and timeframes of realistic usability to be set up. Two primary parts of medication item that assume vital part in timeframe of realistic usability determination are test of dynamic medication and degrades created, amid soundness study. Cutting edge techniques for decision for quantitative examination are UV, HPLC, GC, GCMS, LCMS and HPTLC which are very advanced. Chromatographic routines are normally utilized as part of administrative labs for subjective and quantitative examination of medication substances, drug items, crude materials and natural examples all through all periods of medication advancement from exploration to quality control 2. Superior fluid chromatography (HPLC) is quickest developing diagnostic strategy for investigation of medications. Its effortlessness, high specificity and extensive variety of affectability make it perfect for examination of numerous medications in both measurement shapes and organic liquids. High performance thin-layer chromatography (HPTLC) is classical separative technique that has enjoyed wide spread popularity particularly in analysis of complex mixtures of natural origin. Now-a-days HPTLC is turning into routine investigative method because of its preferences of low working expense, high specimen throughput and requirement for least example clean-up. significant point of preference of HPTLC is that few specimens can be run at same time utilizing little amount of versatile stage not at all like HPLC, in this way bringing down examination time and expense per investigation 3 .

\section{Chromatography}

Today, chromatographic techniques have little to do with the separation of color (the technique names evolved from the earliest work of separating dyes or plant pigments on paper), but do involve the separation of compounds in a sample mixture. A number of types of separation methods have developed over the years to accommodate the various physical and chemical states of sample mixtures one may be interested in separating and analyzing. The feature that distinguishes chromatography from most other physical and chemical methods of separation is that, two mutually immiscible phases brought into contact; one phase is stationary and other mobile. The mobile phase can be gas or a liquid, where as the stationary phase can only be a liquid or a solid. When the separation involves predominantly a simple portioning between two immiscible liquid phases, one stationary and other mobile, the process is called liquidliquid chromatography. When physical surface forces are mainly involved in the retentive ability of the stationary phase, the process is denoted as liquid solid chromatography. Liquid chromatography has been performed in a column or on an open bed ${ }^{4-7}$.

\section{MATERIAL AND METHODS}

\section{Acetylsalicylic acid}

Description:
Also known as Aspirin, acetylsalicylic acid (ASA) is a commonly used drug for the treatment of pain and fever due to various causes. Acetylsalicylic acid has both antiinflammatory and antipyretic effects. This drug also inhibits platelet aggregation and is used in the prevention of blood clots stroke, and myocardial infarction (MI).

Molecular formula: $\mathrm{C}_{9} \mathrm{H}_{8} \mathrm{O}_{4}$

Molecular weight: $180.1574 \mathrm{~g} / \mathrm{mol}$

Chemical name: 2-(acetyloxy) benzoic acid

Synonym: Acid acetyl salicylique

Physical Description: Solid

\section{Domperidone}

\section{Description:}

A specific blocker of dopamine receptors. It speeds gastrointestinal peristalsis, causes prolactin release, and is used as antiemetic and tool in the study of dopaminergic mechanisms.

\section{Molecular formula: C22H24CIN5O2}

Molecular weight: $425.911 \mathrm{~g} / \mathrm{mol}$

Chemical name: 5-chloro-1-\{1-[3-(2-oxo-2,3-dihydro- $1 \mathrm{H}-$ 1,3-benzodiazol-1-yl)propyl]piperidin-4-yl\}-2,3-dihydro-1H1,3-benzodiazol-2-one

\section{Physical Description: Solid}

\section{Identification and Characterization of drugs}

\section{IR spectrum of Aspirin and Domperidone:}

The concentration of the sample in $\mathrm{KBr}$ should be in the range of $0.2 \%$ to $1 \%$. The pellet is much thicker than a liquid film, hence a lower concentration in the sample is required (Beer's Law). For the die set that you will be using, about 80 mg of the mixture is needed. Too high of a concentration causes usually difficulties to obtain clear pellets. This pellet keeps into the sample cell and scanned between 4000-400 $\mathrm{cm}^{-1}$ and IR spectra is obtained.

\section{Solubility:}

Solubility of the drug was determined by taking some quantity of drug (about 1-2 mg) in the test tube separately and added the $5 \mathrm{ml}$ of the solvent (water, methanol, $0.1 \mathrm{~N}$ $\mathrm{HCl}, 0.1 \mathrm{~N} \mathrm{NaOH}$, acetonitrile) Shake vigorously and kept for some time. Note the solubility of the drug in various solvents (at room temperature) ${ }^{8}$.

\section{Melting point:}

\section{Procedure for determine melting point:}

A little quantity of Aspirin and Domperidone were set into a fusion tube. That tube was set in the melting point deciding contraption (Chemline, CL-725) containing castor oil. The temperature of the castor oil was progressive expanded consequently and read the temperature at which powder began to liquefy and the temperature when all the powder gets softened.

\section{Determination of $\lambda$ max of Aspirin and Domperidone:}

The $\lambda$ max of Aspirin and Domperidone were determined by running the spectrum of drug solution in double beam ultraviolet spectrophotometer.

\section{Method development of Aspirin and Domperidone:}

Method development and validation for estimation of Aspirin and Domperidone using RP-HPLC. 


\section{Selection of Mobile Phase:}

Initially to estimate Aspirin and Domperidone in fix dosage form number of mobile phase in different ratio were tried.

Taking into consideration the system suitability parameter like RT, Tailing factor, No. of theoretical plates and HETP, the mobile phase found to be most suitable for analysis was 10 $\mathrm{mM} \mathrm{KH} 2 \mathrm{PO}$ : acetonitrile ( $\mathrm{pH} 3.5$ with OPA) in the ratio of $20: 80 \mathrm{v} / \mathrm{v}$. The mobile phase was filtered through $0.45 \mu$ filter paper to remove particulate matter and then degassed by sonication. Flow rate employed for analysis was 1.0 $\mathrm{ml} / \mathrm{min}^{10}$.

\section{Procedure for preparation of mobile phase:}

$10 \mathrm{mM} \mathrm{KH}_{2} \mathrm{PO}_{4}$ : acetonitrile $(\mathrm{pH} 3.5)$ in the ratio of $20: 80 \mathrm{v} / \mathrm{v}, \mathrm{pH} 3.0$ with Ortho phosphoric acid. Filtered through $0.45 \mu$ filter paper.

\section{Selection of Diluent:}

Diluent used for preparation of sample were compatible with mobile phase and no any significant affect retention and resolution of analyte. After various trials Acetonitrile was used as diluents.

\section{Selection of separation variable:}

1. Preparation of standard Stock solution Accurately weighed $10 \mathrm{mg}$ of Aspirin and Domperidone was transferred into $10 \mathrm{ml}$ volumetric flasks separately and dissolved in $5 \mathrm{ml}$ of acetonitrile and sonicate for $10 \mathrm{~min}$., then volume was made up to $10 \mathrm{ml}$ with acetonitrile. Concentration of Aspirin and Domperidone in acetonitrile was $1000 \mu \mathrm{g} / \mathrm{ml}$. (stock- A)

2. Preparation of Sub Stock Solution $1 \mathrm{ml}$ of solution was taken from stock-A of Aspirin and Domperidone and transferred into $10 \mathrm{ml}$ volumetric flask separately and diluted up to $10 \mathrm{ml}$ with diluent (Acetonitrile) to give concentration of $100 \mu \mathrm{g} / \mathrm{ml}$ (Stock-B).

\section{Preparation of Different Solution}

$1 \mathrm{ml}, 2 \mathrm{ml}, 3 \mathrm{ml}, 4 \mathrm{ml}$ and $5 \mathrm{ml}$ of stock-B was taken separately in $10 \mathrm{ml}$ volumetric flask and volume was made up to $10 \mathrm{ml}$ with (Acetonitrile). This gives the solutions of $10 \mu \mathrm{g} / \mathrm{ml}, 20$ $\mu \mathrm{g} / \mathrm{ml}, 30 \mu \mathrm{g} / \mathrm{ml}, 40 \mu \mathrm{g} / \mathrm{ml}, 50 \mu \mathrm{g} / \mathrm{ml}$ for Aspirin. In same manner $1 \mu \mathrm{g} / \mathrm{ml}, 2 \mu \mathrm{g} / \mathrm{ml}, 3 \mu \mathrm{g} / \mathrm{ml}, 4 \mu \mathrm{g} / \mathrm{ml}, 5 \mu \mathrm{g} / \mathrm{ml}$ of Domperidone also prepared.

\section{Linearity and Calibration Graph}

To establish the linearity of analytical method, a series of dilution ranging from $10-50 \mu \mathrm{g} / \mathrm{ml}$ was prepared for aspirin and $1-5$ a $\mathrm{g} / \mathrm{ml}$ for Domperidone. All the solution were filtered through $0.2 \mu \mathrm{m}$ membrane filter and injected, chromatograms were recorded at $231 \mathrm{~nm}$ and it was repeat for three times. A calibration graph was plotted between the mean peak area and respective concentration and regression equation was derived.

\section{System Suitability Parameters:}

Separation variables were set and mobile phase was allowed to saturate the column at $1.00 \mathrm{ml} / \mathrm{min}$. After complete saturation of column, three replicates of working standard of Domperidone $5 \mu \mathrm{g} / \mathrm{ml}$ and $50 \mu \mathrm{g} / \mathrm{ml}$ Aspirin was injected separately. Peak report and column performance report were recorded for all chromatogram.

\section{RESULT AND DISCUSSION}

\section{Identification and Characterization of drugs}

IR spectrum of Aspirin and Domperidone:

The IR spectrum of sample drug shows the peak values which are characteristics of the drug and the graph were shown in figure 1-2.

\section{Solubility:}

Solubility of drug was observed by dissolving them in differentsolvents.

Table 1: Solubility of drug in different solvents

\begin{tabular}{|l|l|l|}
\hline \multirow{2}{*}{ Solvent } & \multicolumn{2}{|l|}{ Results of Solubility } \\
\cline { 2 - 3 } & Aspirin & Domperidone \\
\hline Water & Soluble & Slightly Soluble \\
\hline $0.1 \mathrm{~N} \mathrm{HCl}$ & Soluble & Soluble \\
\hline $0.1 \mathrm{~N} \mathrm{NaOH}$ & Insoluble & Soluble \\
\hline Methanol & Freely soluble & Freely soluble \\
\hline Acetonitrile & Soluble & Soluble \\
\hline
\end{tabular}

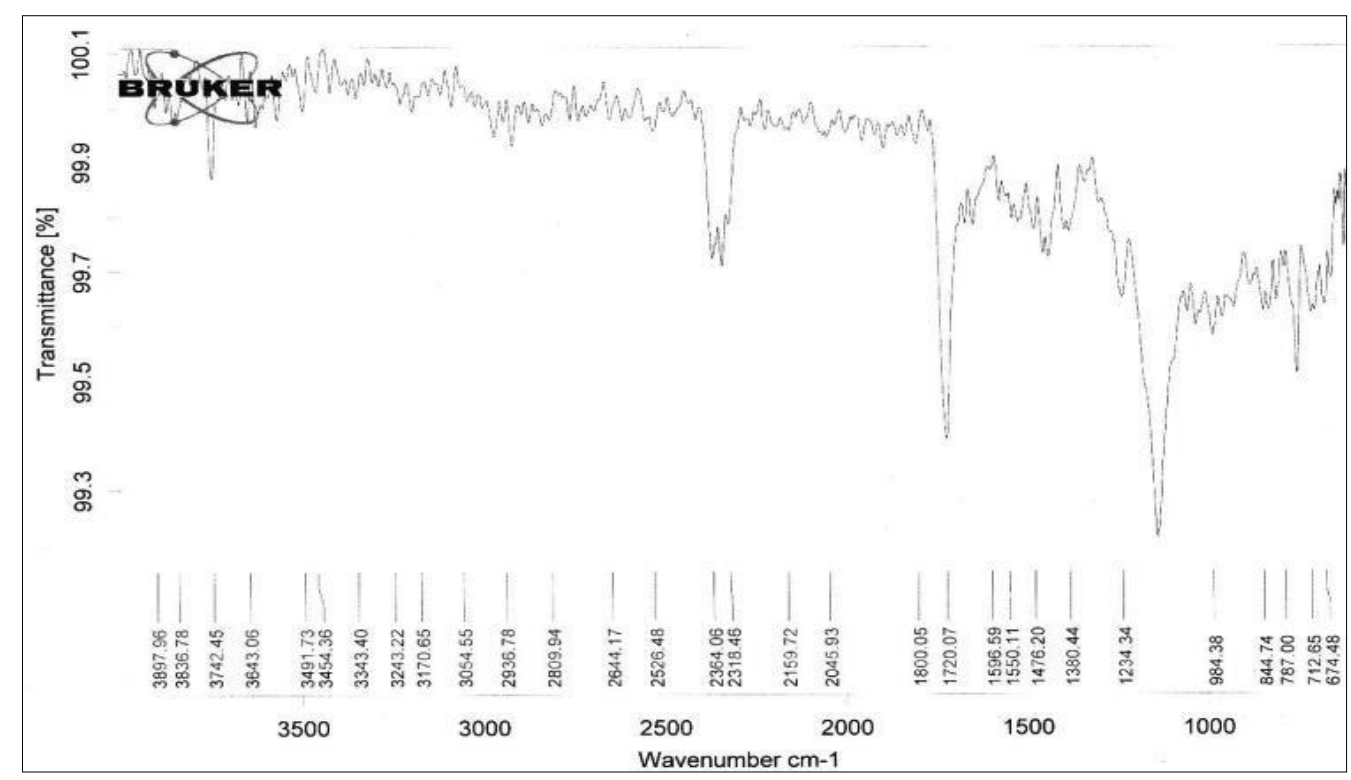

Figure 1: FT-IR Spectrum of Pure Drug (Aspirin) 


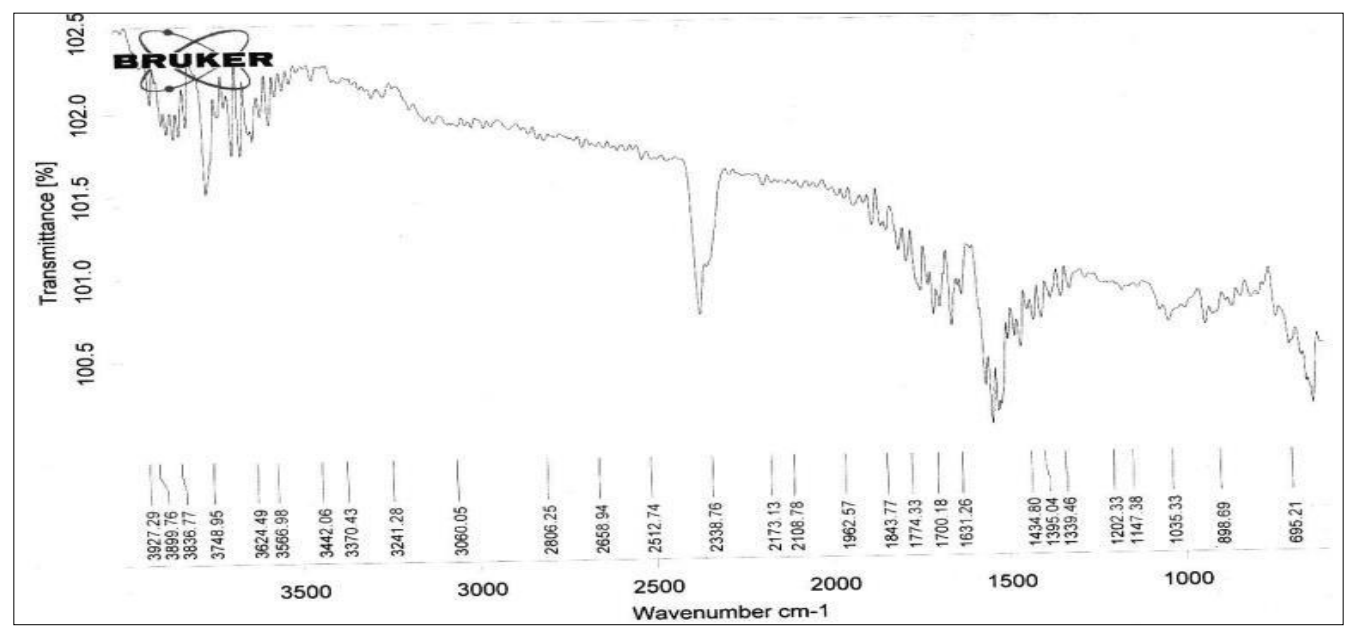

Figure 2: FT-IR Spectrum of Pure Drug (Domperidone)

\section{Melting point:}

Melting point of Aspirin and Domperidone was found 132$133^{\circ} \mathrm{C}$ and $240-241^{\circ} \mathrm{C}$ respectively through Melting point apparatus.

\section{Determination of $\boldsymbol{\lambda} \max$ of Aspirin and Domperidone:}

Standard solution $(10 \mu \mathrm{g} / \mathrm{ml})$ of Aspirin and Domperidone was prepared. The pure drug solution was scanned on UV spectrophotometer, and $\lambda$ max was determined.

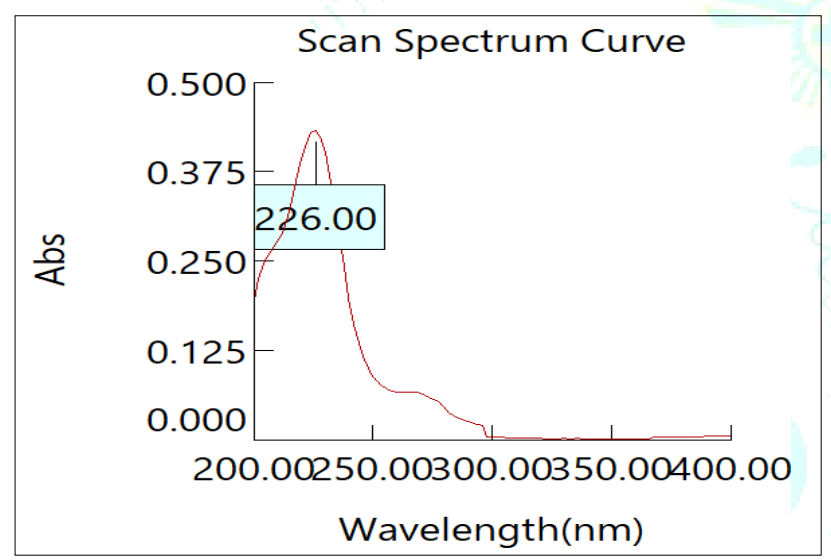

Figure 3: Determination of $\lambda_{\max }$ of Aspirin

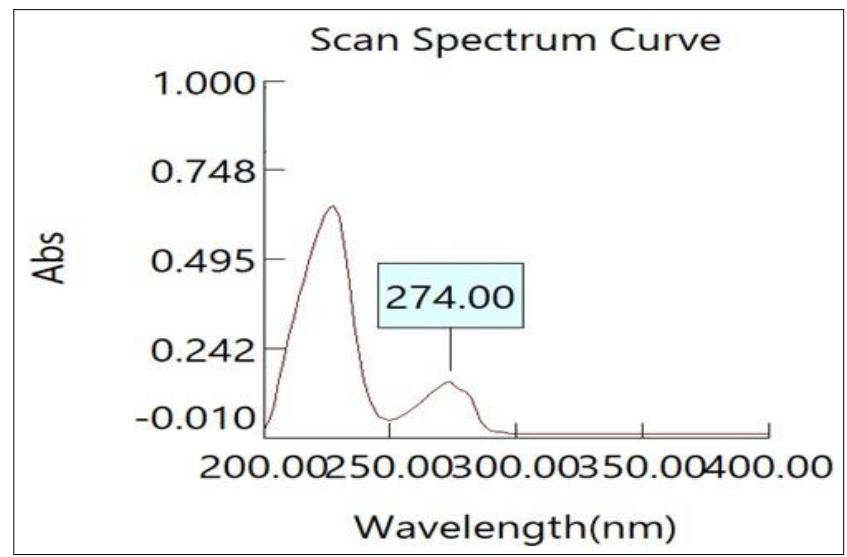

Figure 4: Determination of $\lambda_{\max }$ of Domperidone

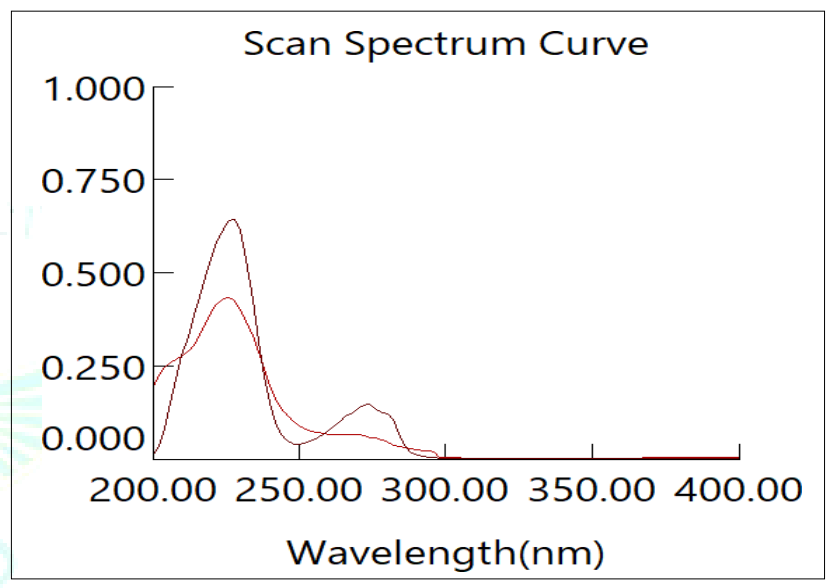

Figure 5: Overlain spectra of Aspirin and Domperidone

Method development of Aspirin and Domperidone:

Method development and validation for estimation of Aspirin and Domperidone using RP- HPLC.

\section{Selection of Mobile Phase:}

Initially to estimate Aspirin and Domperidone in fix dosage form number of mobile phase in different ratio were tried. A result was shown in Table 1.

Taking into consideration the system suitability parameter like RT, Tailing factor, No. of theoretical plates and HETP, the mobile phase found to be most suitable for analysis was 10 $\mathrm{mM} \mathrm{KH} 2 \mathrm{PO} 4$ : acetonitrile ( $\mathrm{pH} 3.5$ with OPA) in the ratio of $20: 80 \mathrm{v} / \mathrm{v}$. The mobile phase was filtered through $0.45 \mu$ filter paper to remove particulate matter and then degassed by sonication. Flow rate employed for analysis was 1.0 $\mathrm{ml} / \mathrm{min}$.

Procedure for preparation of mobile phase:

$10 \mathrm{mM} \mathrm{KH} 2 \mathrm{PO} 4$ : acetonitrile $(\mathrm{pH} 3.5)$ in the ratio of $20: 80 \mathrm{v} / \mathrm{v}$, pH 3.0 with Ortho phosphoric acid. Filtered through $0.45 \mu$ filter paper.

Table 2: Mobile Phase Selection

\begin{tabular}{|l|l|l|}
\hline Solvent & Ratio & Observation \\
\hline $\begin{array}{l}\text { 10 mM KH2PO4: } \\
\text { acetonitrile (pH 3.5) }\end{array}$ & $20: 80 \mathrm{v} / \mathrm{v}$ & $\begin{array}{l}\text { Both sharp peak was } \\
\text { observed (Most suitable) }\end{array}$ \\
\hline
\end{tabular}




\section{Selection of Diluent:}

Diluent used for preparation of sample were compatible with mobile phase and no any significant affect retention and resolution of analyte. After various trials Acetonitrile was used as diluents.

\section{Selection of separation variable:}

Table 2: Separation Variable

\begin{tabular}{|l|l|}
\hline Variable & Condition \\
\hline Particle Size & $5 \mu$ \\
\hline Bonded Phase & Octadecylsilane (C18) \\
\hline Mobile Phase & $10 \mathrm{mM} \mathrm{KH} 2 \mathrm{PO} 4:$ acetonitrile $\mathrm{pH} 3.5)$ \\
\hline $10 \mathrm{mM} \mathrm{KH} 2 \mathrm{PO} 4$ & 20 \\
\hline Acetonitrile & 80 \\
\hline Diluent & Acetonitrile \\
\hline Flow rate & $1.0 \mathrm{ml} / \mathrm{min}$ \\
\hline Temperature & Ambient \\
\hline Sample Size & $20 \mu$ \\
\hline Detection wavelength & $231 \mathrm{~mm}$ \\
\hline Aspirin & $2.112 \pm 0.3 \mathrm{~min}$ \\
\hline Domperidone & $4.316 \pm 0.3 \mathrm{~min}$ \\
\hline
\end{tabular}

\section{Preparation of standard Stock solution:}

Accurately weighed $10 \mathrm{mg}$ of Aspirin and Domperidone was transferred into $10 \mathrm{ml}$ volumetric flasks separately and dissolved in $5 \mathrm{ml}$ of acetonitrile and sonicate for $10 \mathrm{~min}$., then volume was made up to $10 \mathrm{ml}$ with acetonitrile. Concentration of Aspirin and Domperidone in acetonitrile was $1000 \mu \mathrm{g} / \mathrm{ml}$. (stock- A)

Preparation of Sub Stock Solution $1 \mathrm{ml}$ of solution was taken from stock-A of Aspirin and Domperidone and transferred into $10 \mathrm{ml}$ volumetric flask separately and diluted up to $10 \mathrm{ml}$ with diluent (Acetonitrile) to give concentration of $100 \mu \mathrm{g} / \mathrm{ml}$ (Stock-B).

Preparation of Different Solution $1 \mathrm{ml}, 2 \mathrm{ml}, 3 \mathrm{ml}, 4 \mathrm{ml}$ and 5 $\mathrm{ml}$ of stock-B was taken separately in $10 \mathrm{ml}$ volumetric flask and volume was made up to $10 \mathrm{ml}$ with (Acetonitrile). This gives the solutions of $10 \mu \mathrm{g} / \mathrm{ml}, 20 \mu \mathrm{g} / \mathrm{ml}, 30 \mu \mathrm{g} / \mathrm{ml}, 40 \mu \mathrm{g} / \mathrm{ml}$ $50 \mu \mathrm{g} / \mathrm{ml}$ for Aspirin. In same manner $1 \mu \mathrm{g} / \mathrm{ml}, 2 \mu \mathrm{g} / \mathrm{ml}$, $3 \mu \mathrm{g} / \mathrm{ml}, 4 \mu \mathrm{g} / \mathrm{ml}, 5 \mu \mathrm{g} / \mathrm{ml}$ of Domperidone also prepared.

\section{Linearity and Calibration Graph:}

To establish the linearity of analytical method, a series of dilution ranging from $10-50 \mu \mathrm{g} / \mathrm{ml}$ was prepared for aspirin and $1-5 \mu \mathrm{g} / \mathrm{ml}$ for Domperidone. All the solution were filtered through $0.2 \mu \mathrm{m}$ membrane filter and injected, chromatograms were recorded at $231 \mathrm{~nm}$ and it was repeat for three times. A calibration graph was plotted between the mean peak area and respective concentration and regression equation was derived.

Table 3: Linearity of Aspirin

\begin{tabular}{|c|c|c|c|c|c|c|c|}
\hline \multirow{2}{*}{$\begin{array}{l}\text { Standard } \\
\text { Concentration } \mu \mathrm{g} / \mathrm{ml}\end{array}$} & \multicolumn{5}{|c|}{ Area under Curve (AUC) } & \multirow[b]{2}{*}{ Rep-6 } & \multirow[t]{2}{*}{ Mean } \\
\hline & Rep-1 & Rep-2 & Rep-3 & Rep-4 & Rep-5 & & \\
\hline 0 & 0 & 0 & 0 & 0 & 0 & 0 & 0 \\
\hline 10 & 235.654 & 240.565 & 229.896 & 230.478 & 245.587 & 231.658 & 235.640 \\
\hline 20 & 465.658 & 475.658 & 460.587 & 455.698 & 472.125 & 479.985 & 468.285 \\
\hline 30 & 699.854 & 705.658 & 713.458 & 445.569 & 685.458 & 679.985 & 654.997 \\
\hline 40 & 935.471 & 925.698 & 930.145 & 940.587 & 928.741 & 920.325 & 930.161 \\
\hline 50 & 1170.658 & 1165.254 & 1169.987 & 1176.654 & 1175.654 & 1180.325 & 1173.089 \\
\hline Correl Coeff $\left(\mathrm{r}^{2}\right)$ & & & & & & & 0.998 \\
\hline Slope (m) & & & & & & & 23.24 \\
\hline Intercept (c) & & & & & & & -4.094 \\
\hline
\end{tabular}

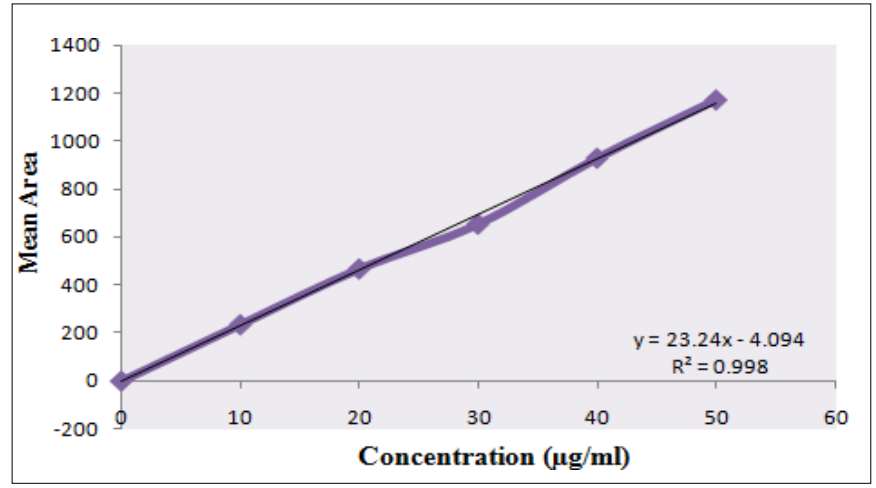

Figure 6: Calibration Curve of Aspirin 


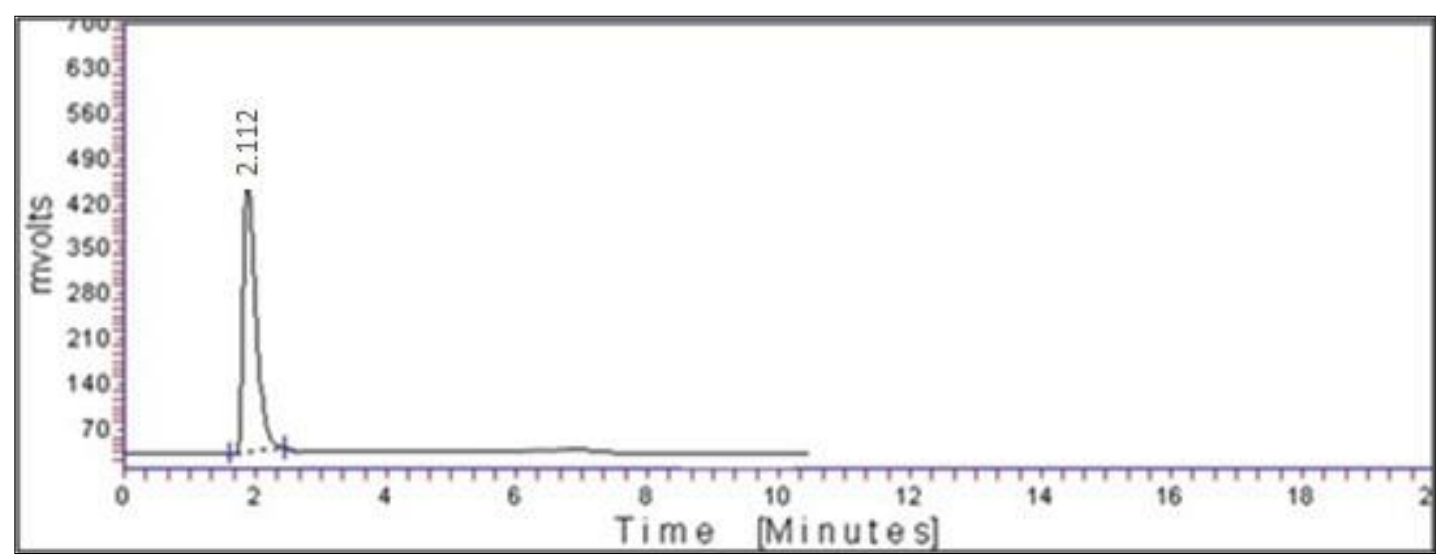

Figure 7: Chromatogram of Aspirin

Table 7.4: Linearity of Domperidone

\begin{tabular}{|c|c|c|c|c|c|c|c|}
\hline \multirow[b]{2}{*}{$\begin{array}{c}\text { Standard } \\
\text { Concentration } \\
\mu \mathrm{g} / \mathrm{ml}\end{array}$} & \multicolumn{5}{|c|}{ Area under Curve (AUC) } & \multirow[b]{2}{*}{ Rep-6 } & \multirow[t]{2}{*}{ Mean } \\
\hline & Rep-1 & Rep-2 & Rep-3 & Rep-4 & Rep-5 & & \\
\hline 0 & 0 & 0 & 0 & 0 & 0 & 0 & 0 \\
\hline 1 & 95.569 & 98.856 & 92.325 & 98.789 & 96.658 & 93.321 & 95.920 \\
\hline 2 & 186.658 & 180.125 & 189.658 & 182.325 & 175.658 & 193.321 & 184.624 \\
\hline 3 & 276.458 & 270.325 & 275.658 & 265.589 & 273.325 & 269.987 & 271.890 \\
\hline 4 & 365.458 & 360.254 & 369.987 & 345.658 & 372.325 & 360.458 & 362.357 \\
\hline 5 & 465.581 & 470.586 & 475.658 & 460.325 & 470.325 & 478.954 & 470.238 \\
\hline Correl Coeff $\left(\mathrm{r}^{2}\right)$ & & & & & & & 0.998 \\
\hline Slope $(\mathrm{m})$ & & & & & & & 92.50 \\
\hline Intercept (c) & & & & & & & -0.430 \\
\hline
\end{tabular}

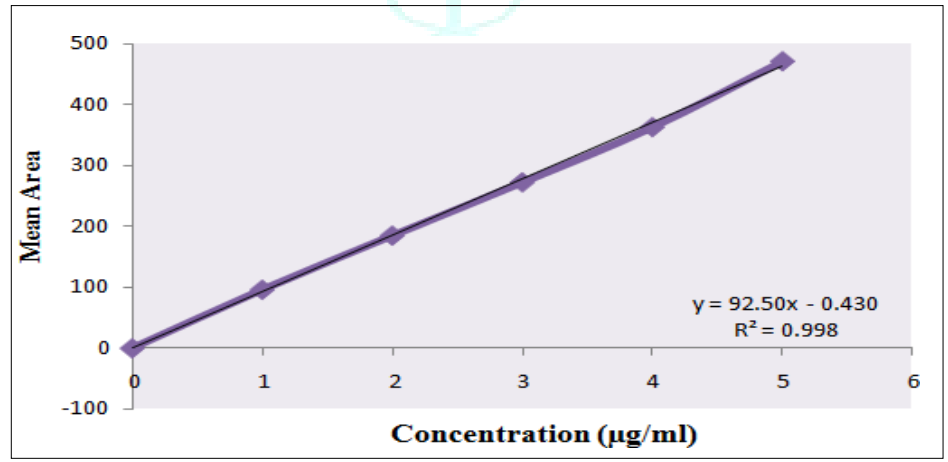

Figure 8: Calibration Curve of Domperidone

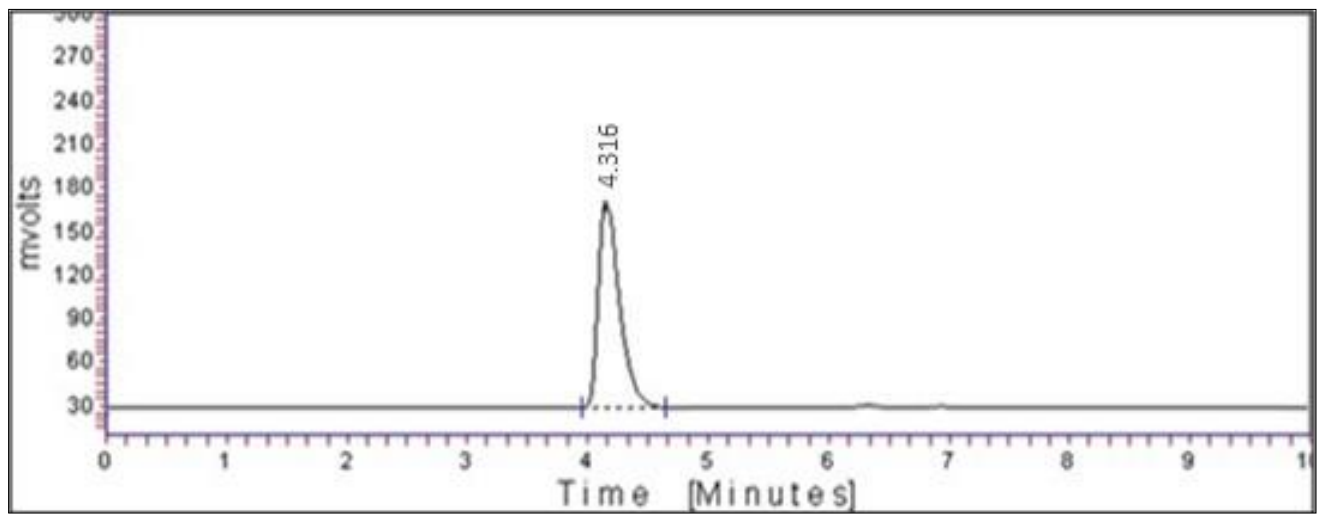

Figure 9: Chromatogram of Domperidone 


\section{System Suitability Parameters:}

Separation variables were set and mobile phase was allowed to saturate the column at $1.00 \mathrm{ml} / \mathrm{min}$. After complete saturation of column, three replicates of working standard of Domperidone $5 \mu \mathrm{g} / \mathrm{ml}$ and $50 \mu \mathrm{g} / \mathrm{ml}$ Aspirin was injected separately. Peak report and column performance report were recorded for all chromatogram.

Table 5: System Suitability Parameters of Aspirin

\begin{tabular}{|l|l|l|l|l|}
\hline $\begin{array}{l}\text { System suitability } \\
\text { Parameter } \mu\end{array}$ & RT & AUC & No. of theoretical plates & Tailing factor \\
\hline Rep-1 & 2.112 & 1170.658 & 3256 & 1.25 \\
\hline Rep-2 & 2.113 & 1165.254 & 3156 & 1.26 \\
\hline Rep-3 & 2.114 & 1169.987 & 3265 & 1.32 \\
\hline Rep-4 & 2.114 & 1176.654 & 3156 & 1.25 \\
\hline Rep-5 & 2.113 & 1175.654 & 3255 & 1.32 \\
\hline Rep-6 & 2.116 & 1180.325 & 3265 & 1.45 \\
\hline Mean & 2.114 & 1173.089 & 3225.500 & 1.308 \\
\hline S.D. & 0.001 & 5.451 & 54.003 & 0.077 \\
\hline \% R.S.D. & 0.065 & 0.465 & 1.674 & 5.869 \\
\hline
\end{tabular}

Table 6: System Suitability Parameters of Domperidon

\begin{tabular}{|l|l|l|l|l|}
\hline $\begin{array}{l}\text { System suitability } \\
\text { Parameter } \mu\end{array}$ & RT & AUC & Nof theoretical plates & \\
\hline Rep-1 & 4.316 & 465.581 & 3250 & 1.45 \\
\hline Rep-2 & 4.325 & 470.586 & 3150 & 1.46 \\
\hline Rep-3 & 4.321 & 475.658 & 3250 & 1.45 \\
\hline Rep-4 & 4.326 & 460.325 & 3050 & 1.44 \\
\hline Rep-5 & 4.329 & 470.325 & 3150 & 1.46 \\
\hline Rep-6 & 4.322 & 478.954 & 3250 & 1.52 \\
\hline Mean & 4.323 & 470.238 & 3183.333 & 1.463 \\
\hline S.D. & 0.005 & 6.715 & 81.650 & 0.029 \\
\hline \% R.S.D. & 0.105 & 1.428 & 2.565 & 1.965 \\
\hline
\end{tabular}

\section{CONCLUSION}

In the present research work, a successful attempt was made for "Method Development and Validation for the Estimation of Domperidone and Aspirin in Bulk or Formulation Using UV and HPLC" which was developed by experimentation based on thorough literature survey and ascertained by statistical parameters of sampling. The simplicity, rapidity, accurate and reproducibility of the proposed methods completely fulfill the objective of the research work of estimation of the drugs. Liquid chromatographic system from waters comprising of manual injector, waters 515 pumps for constant flow and constant pressure delivery and UV Visible Detector connected to data ace software for controlling the instrumentation as well as processing the data generated were used. Drug sample was extracted by precipitating method using $5 \mathrm{ml}$ of methanol for each $\mathrm{ml}$ of plasma sample. The proposed methods were found to be linear with correlation coefficient close to one. Precision was determined by repeatability, Intermediate precision and reproducibility of the drugs. The robustness of developed method was checked by changing in the deliberate variation in solvent. The result obtained shows the developed methods to be Cost effective, Rapid (Short retention time), Simple, Accurate (the value of SD and \% RSD less than 2), Precise and can be successfully employed in the routine analysis of these drugs in bulk drug as well as in tablet dosage form. The Simplicity, Rapidly and Reproducibility of the proposed method completely fulfill the objective of this research work. 


\section{REFERENCES}

1. Sharma BK. Instrumental methods of chemical analysis, Introduction to Analytical chemistry: Goel Publishing House Meerut, 23th edition; 2004.

2. Saeed AM, Hamzah MJ, Ahmed NQ. Quantitative assay of aspirin and (salicylic acid and heavy metals as impuraties) in Iraqi's market aspirin tablets using different analytical methods. International Journal of Applied Pharmaceutics, 2018; 10(5):167-172.

3. Willard HH, Merritt LL, Dean JJA, Frank AS. Instrumental method of analysis: CBS Publishers and Distributors, New Delhi, $7^{\text {th }}$ Edition; 1986

4. Mendham J, Denney RC, Barnes JD, Thomas MJ, Chemical analysis, Vogel's Textbook of Quantitative Chemical Analysis, Pearson Education Asia, Singapore, $6^{\text {th }}$ edn., 2002,1-11.

5. Chatwal GR, Ed AM. Quality Control in Pharmacy; Pharmaceutical Chemistry-Inorganic, Himalaya Publication House, Mumbai, 2nd edn., 1999, 1:25-27.

6. Backett $\mathrm{AH}$, Stenlake JB, Davidson A. Instrumental Method in the development and use of medicines; Practical Pharmaceutical Chemistry, CBS Publishers and Distribution New Delhi, $4^{\text {th }}$ edn., 2002; 2(1-8):85-174.

7. Ahuja S, Scypinski S, Crowther JB. Validation of Pharmaceutical Text Method; Handbook of Modern Pharmaceutical Analysis. Academic Press, London, 2001, 415445 .

8. Sherman RE, Rhodes LJ. Analytical Instrumentation; Practical Guides for Measurement and Control, Instrument Society of America.1996, 647-648.

9. Gennaro AR, Karen BM, Medwick T. Remington ; The Science and Practice of Pharmacy, Mach Publishing Company, Pennsylvania, 19th edn., 1995; 1:437-490.
10. Willard HH, Merritt LL, Dean JA, Settle FA. HPLC Theory and Instrumentation; In Instrumental Methods of Analysis, CBS Publishers and Distributors, New Delhi, 8th edn., 2002, 1-12.

11. Snyder LR, Kirkland JJ, Glajch LJ. Getting Started; In Practical HPLC Method Development, John Willey and Sons, Inc, New York, $2^{\text {nd }}$ edn., 1997,5-17.

12. Snyder LR, Kirkland JJ, Glajch LJ. Non-ionic Samples; Reversedand Normal-Phase HPLC, In Practical HPLC Method Development, John Wiley and Sons, Inc, New York, 2nd edn. 1997, 233-291.

13. Billiet HAH, Rippel G. Method Development and Selectivity Optimization in High-Performance Liquid Chromatography; In Advances in Chromatography, Marcel Dekker, Inc, New York, 1998; 39:263-310.

14. Sharaf MA. Assessment of Chromatographic Peak Purity; In Advances in hromatography, Market Dekker, Inc, New York, 1997; 37:1-6.

15. Cindy Green. J Vali Teach, In; Analytical method validation. RAC 2000; 6:625- 31.

16. Peter EW. Thin- Layer Chromatography: A modern practical approach. Thomas Graham House, Science Park, Milton Road, Cambridge, UK: The Royal Society of chemistry; 2005.

17. Elhance DN. Foundation of statistics. Kitab mahal, 47th edn; 2003.

18. Ali RMA, Mohammed AAB, Mohammed T, Zainab AJ. Development Method for Determination of Aspirin as Sodium Salicylate by UV-VIS Spectroscopy. IOP Conference Series Materials Science and Engineering. 2019; 571:1-14. 